\title{
Preface, 2010
}

President Obama hushed the audience at a Democratic fundraiser in February 20 Io with a story he did not tell lightly. An uninsured Obama volunteer from St. Louis was dying from breast cancer. (Unspoken: just like my mother died from ovarian cancer while struggling with an insurance company.) "She insisted she is going to be buried in an Obama T-shirt," the president continued. "How can I say to her, 'You know what, we're giving up'? How can I say to her family, 'This is too hard'? How can Democrats on the Hill say, 'This is politically too risky'? How can Republicans on the Hill say, 'We're better off just blocking anything from happening'?"1

The faithful sprang to their feet and the familiar incantation filled the hall: "Yes we can! Yes we can!"

A month earlier it had looked like they could and they would. The House had squeezed out its version of national health reform (220-2 I 5 ) on November 7, 2009, the Senate managed its own bill on December 24 (without a single vote to spare), and Congressional leaders began negotiating the differences between the two bills. Suddenly, in mid-January, one of the strangest twists in health reform's long, tortured history sent the president's program sprawling just inches from the finish line. A little-known Republican who had pledged to stop Obama's health plan won a special election in an upset and took the seat long held by Senator Ted Kennedy, the lion of health care reform. Newly elected Senator Scott Brown looked like he could deliver on his campaign promise. He 
gave the united Republicans the 4Ist vote that could sustain the filibuster that would greet the final plan when it came up for a last vote in the Senate.

Democrats panicked. If Republicans could win in Massachusetts, they could win anywhere. Health reformers could feel the plan's momentum evaporating into the frigid Washington winter. The Democrats, it seemed, were about to fail again. No matter how close they got, no matter how clever their legislative maneuvering, no matter how shrewdly they negotiated with the interest groups (and this time most past opponents signed up for reform), health care-the signature Democratic issue for more than sixty years-always eluded the reformers. It was always a bridge too far.

President Obama faced a choice. He had spent his administration's first year fighting for health care. But public opinion had gone south on the reform. Opponents were in full cry, moderates were wary, and polls showed that the public had no idea what was actually in the bill. Many Democrats urged Obama to make the expedient choice and pivot from health care to the issue that seemed to preoccupy most Americans: jobs. Perhaps he could propose a modest health care compromisecover children, for example, or regulate insurance companies to curb practices like denying coverage to patients with preexisting illnesses.

Or he could go for broke. He could put his presidency-and perhaps his legacy-on the line for a complicated, heavily compromised, and increasingly unpopular reform. What would he do? Which way would the cool, cerebral, calculating man-no drama Obama-decide to go?

Future historians will search for the motivations that led Barack Obama to take his big gamble and push ahead with an intricate but ultimately successful maneuver around the Senate filibuster. Few presidents have put as much on the line for a single reform, for a single vote. Did the gamble pay off? Did the legislation improve American health care? Did it tip the balance of power between the parties?

Time will answer these questions, of course. But one thing, we believe, is already clear. President Obama accomplished what almost every Democratic president-Harry Truman, John Kennedy, Jimmy Carter, and Bill Clinton-aspired to and failed. His accomplishment invites us to revisit some of the central lessons of health reform. In many ways, he followed those history lessons. In at least one big way he fell short. But his most impressive moment came-like Harry Truman'safter his reform was imperiled.

Begin with what this president did right. 
First, he cared about health care-far more than his cool demeanor suggests. From campaign stories about his mother's illness, through countless setbacks and crises over the long Congressional deliberations of 2009, to that evocative tale of a dying uninsured loyalist, health care clearly stuck in Obama's gut. He would not, did not, give up. In East Room remarks before finally signing the hard-won legislation on March 23, 20IO, he listed the reasons he had persisted. The first was closest to home: "I did this for my mother."

Second, he acted fast. After a brief postinaugural detour to pass an economic stimulus bill (which contained several important health reform provisions), the administration pressed to get health reform in Obama's first year in office. Here was a president who had learned the lessons of LBJ's success with Medicare-move during the honeymoon, don't let dead cats stink up the porch (see chapter 5). The Obama team also understood the Clinton administration's catastrophic delay. Contrast the Clinton and Obama reform clocks: Obama's legislation made it through the Senate-after nine months of turbulent politics-in late December, year I, at precisely the same point (late December, year I) that the Clinton team finally submitted its proposal to Congress.

Third, Obama had a plan on arrival—not a 2,000-page bill, but an approach, a set of principles, that he announced in May 2007 and from which he did not depart. The legislation would dramatically extend coverage by correcting defects in the private insurance market and by providing uninsured Americans the means to purchase private coverage. Employers had to step up, in some form, to guarantee coverage to employees. Health delivery reform through prevention, chronic disease management, and health information technology had to be part of the program. Costs had to be addressed. Ironically, the plan was well to the right of Nixon's I 974 proposal. In fact, its closest predecessor was the DoleChafee plan constructed as a Republican alternative to Clinton in 1994. It fell short of what the party faithful had hoped for, but it was a foundation to build on.

Fourth, Obama managed his economists and the economics. Though future scholars will shed light on the memos and the meetings, the administration's decision to expend hundreds of billions on health care-on top of the nearly $\$ 900$ billion stimulus plan-must have caused sweaty palms and palpitations among dismal scientists in the White House. When the president carved out space for health reform in his proposed economic program for 2009 , the die was cast. Later, in September, he calmed jittery nerves among moderate congressional 
Democrats by promising a bill that would cost less than \$ I trillion and not add "a dime" to the deficit.

Fifth, he went public. He had campaigned on health care, talked about it in Spring 2009, and repeatedly set public deadlines for Congressional action. Even so, the Democrats lost control of the public debate during a long, hot summer of Tea Party activism. Even a powerful September speech before a joint session of Congress-where Congressman Joe Wilson's (R-SC) audible "you lie!" reflected the heat of the controversy-did not turn national sentiment toward health reform. But in the chaotic weeks after the Democrats lost their 6oth Senate vote, the president found his voice. He rallied his party in a way reminiscent of Harry Truman giving 'em hell in I948 or John Kennedy stumping for Medicare after his father's stroke in 1962.

Sixth, the president managed the Congress. He has been criticized for standing back and letting Congress do the drafting. This view, we believe, is naïve about both congressional process and history. Lyndon Johnson and George W. Bush each got results with firm principles and deference on the details. ("I am not trying to go into details," LBJ repeatedly told Ways and Means chair Wilbur Mills in I964. Johnson always called Medicare "the Mills Bill.") In contrast, the Clinton administration tried to write a detailed bill that congressional committee chairs promptly rewrote or replaced. Presidents Johnson, Bush, and Obama got much further by asking Congress to work from the administration's broad campaign blueprint. The legislative process was not pretty, but it did the job.

Seventh, unlike Jimmy Carter and Bill Clinton, Obama seemed to stay out of the health policy weeds. During convoluted technical debatesabout Cadillac health plan taxes, public options, the design of health insurance exchanges, or the power of Medicare cost-containment commissions-the White House batted away pleas to jump into the mud wrestling. Occasionally the president would lob a pronouncement down Pennsylvania Avenue: he supported a public plan, he was flexible on an individual mandate. But for the most part, when he rolled up his sleeves, it was to do what only presidents can do: manage the politics, stiffen the backs of skittish Blue Dog Democrats, or bring disappointed liberals back to the table. Future historians will puzzle out whether President Obama got it exactly right-perhaps he might have intervened more or sooner. But he avoided the temptation to "dive into the PSROs" (see chapter 7)-the nitty-gritty, wonky details that had beguiled some of his failed predecessors. 
Finally, the president confronted the toughest lesson that history offers Oval Office health reformers: know how to lose. In the January 2010 State of the Union Address, his party in chaos after the loss of its filibuster-proof Senate majority, Obama stepped back into the fray: "Don't walk away from reform," he told the Congress and the American people. "Not now. Not when we are so close. Let us find a way to come together and finish the job for the American people. Let's get it done." In I994, Clinton fled the field, ceding the ground to his enemies and leaving health care in the policy wilderness for over a decade. In 20I0, Obama did the reverse. His voice grew louder, clearer, more confident as the Democrats fell into disarray. He pushed to get Republicans, as well as Democrats, to own this issue and to take responsibility for fixing a broken system. If he had failed, perhaps his loss-like Truman's or Kennedy's-would have set the stage for another round of health care debate, rather than marking the issue as radioactive. In the end, Obama uncovered a great irony: by knowing how to lose, he won.

We see failings as well as successes in Obama's management of health reform. Lyndon Johnson, the master of the Senate, might very well have found a way to short-circuit the prolonged unsuccessful negotiations between Senators Charles Grassley (R-IA) and Max Baucus (D-MT) that stalled health reform in the Senate, breaching Obama's deadlines and allowing the debate to slip into the near disastrous summer of opposition. Perhaps Obama—and Democrats like Senator Baucuspermitted the chimera of bipartisanship to cloud his political judgment. Perhaps Obama simply didn't have the magic touch, the deeply honed personal instincts and relationships, that gave LBJ the sense of when and how far to push his former Senate colleagues.

While the White House and Democrats focused too long on the inside game of congressional negotiation, they lost control of the public debate. The right-wing populists, self-styled Tea Party activists, roared into the health policy discussion with the 2009 version of "socialized medicine" - the government-run "death panels." The charges—new variations on the trusty old blasts against big government-were simple, pungent, and effective. The administration never found a way to recapture public attention or offer a simple counter to the charges. Like Truman or Clinton before them, the Democrats tried denial (this is not socialized medicine, there are no death panels), backtracking (striking the counseling provisions in the House bill that had set off the storm), and delving into the details (here is what is really in the bill). Once againyet again-the opposition won the battle of popular perception. 
Moreover, the inevitable wheeling and dealing in the House and Senate-there is no other way to pass legislation-was easily ridiculed by the bill's opponents. President Obama never found a way to explain-to connect-how and why his health reform principles were being translated into action by the congressional maneuvers. The White House never managed to sell a persuasive narrative to counter the Tea Party percussion. That failure, in turn, set the scene for the Massachusetts election that almost derailed health reform at the very last moment.

Perhaps health reform also got caught up in larger problems that President Obama struggled to manage. We still live in the philosophical climate set during Ronald Reagan's first inaugural address: celebrate individualism, cheer free markets, and bash the government. This is not fertile ground for national health reform. President Obama campaigned with an alternative. As he told Joe the Plumber, things are better when we spread the wealth around. He invoked the old social gospel vision of community and sharing. Once in office, perhaps wary of the backlash against "welfare" and "handouts," he lost his rhetorical counter to Reaganera individualism. Franklin Roosevelt and John Kennedy had offered a new ideal of politics and society. They lent a framing, a logic, to the eras that followed. Future reformers from both parties might do well to learn that lesson: explain the philosophy that frames your programs.

What next? One story that runs through The Heart of Power focuses on the changes in the political process itself. The most recent edition of health care reform features something brand new: the ferocious politics continues even after the legislation is won. Congressional opponents pledge to fight on-through the courts and into the implementation process.

That fight will further complicate the huge implementation effort. For example, the new legislation includes one provision that bars insurers from "unreasonable premium increase[s]" and another that requires them to spend a minimum amount on "activities that improve health care quality." These vague mandates have to be defined (what is "unreasonable"? how do we set that "minimum"? what counts as improving "quality"?). Then officials have to write the rules that put them into effect. $^{3}$ Implementing any ambitious law is difficult. The political and legal fights that still swirl around the Obama health reform signal an especially rocky road to implementation.

How will we look back on this health care reform? Back in I965, the two parties cooperated once Medicare was won. Even so, implementation was difficult and involved a massive mobilization of national 
resources, the desegregation of the hospitals, a threatened physician strike, and reimbursement deals that built a new level of inflation into the medical system. The final result, of course, was an extremely popular and important program burdened by rising costs. On the other hand, the Reagan administration's Medicare catastrophic care coverage was not even fully implemented before Congress unceremoniously buried the entire thing. Now, the Obama administration will try its hand at implementation. What lies ahead is a mix of politics, negotiation, technical decisions, and court rulings that will determine the political legacy of the Obama administration's signature reform.

Still, we end this preface as we did our first, impressed by the person in the Oval Office. Here is a president who learned the lessons of history. Most important, he internalized the great lesson of Harry Truman: learn to face and manage failure, keep fighting despite defeats. Facing a lost election-and leading a dispirited party-President Obama articulated, clearly and insistently, just what was at stake, why he believed in it, and how to negotiate the path ahead. It may well be the first great lesson of his administration. Again, time will tell.

For now, we watch the Obama health reform experience with renewed humility and respect for the political leaders in the eye of the storm. Health care reform continues to grow more important. It remains politically treacherous. And it still trains an unflinching spotlight on the presidency, on the individual standing at the heart of power.

David Blumenthal and James Morone Brookline, Massachusetts, and Lempster, New Hampshire March 2009

I. Robert Pear and David M. Herszenhorn, "Democrats Ask, Can This Health Care Bill Be Saved?" New York Times, February 6, 20 Iо.

2. Wilbur Mills, telephone audiotape, 9:55 A.M., June 9, I964, "Recordings and Transcripts of Conversations," Citation 3642, LBJ Library.

3. Robert Pear, "Health Insurers Lobbying to Shape Overhaul Rules," New York Times, May i6, 2010. 
This page intentionally left blank 